\title{
Effect of Hyperoxia on Antioxidants in Neonatal Rat Type II Cells in Vitro and in Vivo
}

\author{
KATHLEEN A. KENNEDY, LOUIS S. CROUCH, ${ }^{1}$ AND JOSEPH B. WARSHAW ${ }^{2}$ \\ Department of Pediatrics, University of Texas Southwestern Medical Center, Dallas, Texas 75235
}

\begin{abstract}
Relative resistance to oxygen toxicity in newborn animals (compared to adults) has been associated with increased antioxidant enzymes and glutathione in lung homogenate. The cell type(s) involved in this increase is unknown. We investigated the effect of hyperoxia in vitro and in vivo on the following antioxidants (superoxide dismutase, catalase, glutathione peroxidase, glutathione reductase, glucose-6-phosphate dehydrogenase, and glutathione) in alveolar type II cells from neonatal rats. Type II cells were exposed to $95 \%$ oxygen or air for $48 \mathrm{~h}$ in vitro. When expressed per $\mu \mathrm{g}$ DNA, all the antioxidants except catalase increased during in vitro incubation; only glucose-6-phosphate dehydrogenase and glutathione increased when expressed per mg protein. None of the antioxidants was higher in oxygen-exposed cells than in airexposed cells. Neonatal rats were exposed to $100 \%$ oxygen or air in vivo for $4 \mathrm{~d}$ before determination of antioxidants in lung homogenate supernatant and alveolar type II cells. Catalase, glutathione peroxidase, and glutathione reductase were higher but glucose-6-phosphate dehydrogenase and glutathione were lower in type II cells than in lung homogenate from control animals. Alveolar type II cell glucose-6-phosphate dehydrogenase and glutathione were increased but catalase and glutathione reductase were decreased by exposure to hyperoxia. We conclude that the oxygen-induced increase in whole lung antioxidants is not explained by alveolar type II cell hypertrophy or increased antioxidants within type II cells during hyperoxia. (Pediatr Res 26: 400-403, 1989)
\end{abstract}

\section{Abbreviations}

G6PD, glucose-6-phosphate dehydrogenase

GP, glutathione peroxidase

SOD, superoxide dismutase

GR, glutathione reductase

Oxygen-induced lung injury is thought to result from toxic effects of partially reduced species of molecular oxygen (1), commonly referred to as oxygen free radicals. Production of oxygen free radicals is increased during exposure to hyperoxia, and antioxidant enzymes are believed to protect against cellular

Received February 10, 1989; accepted June 14, 1989.

Correspondence and reprints Kathleen A. Kennedy, M.D., Department of Pediatrics, University of Texas Southwestern Medical Center, 5323 Harry Hines Blvd., Dallas, TX 75235.

Supported by American Lung Association Research Training Fellowship [K.A.K.] and NIH Grant HL36533.

${ }^{1}$ Present address Department of Animal and Exploratory Drug Metabolism, Merck Sharp and Dohme Research Laboratories, Hillsborough Road, Three Bridges, NJ 08887 .

${ }^{2}$ Present address Department of Pediatrics, Yale University School of Medicine, New Haven, CT 06510. damage by free radicals. Neonatal animals of some species (rats, rabbits, and mice) are relatively resistant to toxic effects of hyperoxia when compared to adult animals of the same species (2). This relative resistance is manifested by longer survival in $100 \%$ oxygen and is associated with increased activity of lung antioxidant enzymes (2). This natural protection from oxygeninduced lung injury has been attributed to increased antioxidant enzyme activities despite the fact that the increases are modest $(20-40 \%)$ and result in lower enzyme activity per g of lung tissue than the basal activities of the more susceptible adult animals (3). Protection of adult rats from pulmonary oxygen toxicity can be induced by prior exposure to nonlethal hyperoxia (4) or endotoxin (5). These forms of protection have also been associated with increased antioxidant enzyme activity in lung tissue. Although newborn lambs are similarly protected by endotoxin administration, this protection is not associated with increased antioxidants in lung tissue (6). Thus it remains unclear that increased antioxidants mediate enhanced protection from oxygen toxicity in these animal models.

Of the many cell types present in lung tissue, endothelial cells and alveolar type I cells are most sensitive to oxygen-induced injury. Acute pulmonary oxygen toxicity is histologically manifested by necrosis of these cell types with relative preservation of alveolar type II cells (7). Chronic sublethal hyperoxia is characterized by proliferation and hypertrophy of type II cells and fibroblasts (8). We hypothesized that alveolar type II cells may be more resistant to oxygen-induced injury because these cells are rich in antioxidants. If a specific cell type that is rich in antioxidants is selectively preserved during hyperoxia, antioxidant enzyme activity per $\mathrm{g}$ of lung tissue would increase with prolonged survival in hyperoxia. This increase would not require the ability of individual cells to increase the amount or activity of antioxidants and would occur regardless of the mechanism of enhanced survival.

We investigated this hypothesis by studying the effects of hyperoxia in vitro and in vivo on antioxidant enzymes and glutathione in type II cells from neonatal rats. For comparison, we also measured these antioxidants in whole lung homogenate after in vivo exposure.

\section{MATERIALS AND METHODS}

Oxygen exposure. Newborn Sprague-Dawley rats (Holtzman, Madison, WI) at 1-2 d of age from at least two litters were divided into equal groups for room air or oxygen exposure. Oxygen-exposed neonates were housed with a dam in a plexiglass chamber with continuous flow of oxygen. Analysis of the chamber gas was determined to be $>97 \% \mathrm{O}_{2}$ and $<0.05 \% \mathrm{CO}_{2}$. Dams were rotated daily between oxygen- and air-exposed pups. Based on previous work by others $(3,9)$ and preliminary studies in this laboratory, it was expected that differences in antioxidants would be optimally detected after $4 \mathrm{~d}$ of exposure in vivo.

Preparation of lung homogenate postnuclear supernatant. After $4 \mathrm{~d}$ of oxygen or air exposure, animals were anesthetized with 
an intraperitoneal injection of $0.8-1.2 \mathrm{mg}$ ketamine (Vetalar, Parke-Davis, Morris Plains, NJ) and 200-300 U heparin (Sigma Chemical, St. Louis, MO). Lungs were perfused until pale with iced saline via the right ventricle. Lung tissue was removed and homogenized. The homogenate was centrifuged at $500 \times g$ for $10 \mathrm{~min}$ at $4^{\circ} \mathrm{C}$. The postnuclear supernatant was used for antioxidant assays. Each antioxidant assay was done on at least two separate groups of oxygen- and air-exposed rats.

Type II cell isolation. Type II cells were isolated from the lungs of 5- to 7-d-old rats. For in vivo studies, newborns had been exposed to $4 \mathrm{~d}$ of either oxygen or air as described above just before type II cell isolation. Ten to 20 newborn rats were used for each cell preparation. Type II cells were isolated from newborn lungs by the procedure of Richards et al. (10), which included purification by 30 -min differential adhesion of fibroblasts. Yield was $1-3 \times 10^{6}$ cells per newborn rat. As described by others, the yield from oxygen-exposed rats was consistently lower than the yield from air-exposed rats $(11,12)$. Purity was determined by modified Papanicolaou stain (13) to be $>90 \%$ at the time of isolation and $>95 \%$ of adherent cells after overnight incubation. For in vivo exposure studies, isolated cells were rinsed, resuspended in buffer, and sonicated on ice for antioxidant assays.

For in vitro exposure studies, type II cells were diluted in minimum essential medium with antibiotic/antimycotic solution and $10 \%$ fetal bovine serum (Gibco Laboratories, Grand Island, NY) and plated onto culture dishes (Corning Glass Works, Corning, NY) with $2-4 \times 10^{6}$ cells $/ 35-\mathrm{mm}$ dish. After overnight incubation at $37^{\circ} \mathrm{C}$ in $95 \%$ air, $5 \% \mathrm{CO}_{2}$, nonadherent cells and medium were removed. Adherent cells were harvested as described below for baseline antioxidant assays. The remaining dishes were divided into two groups for in vitro air or oxygen exposure. Oxygen-exposed dishes were incubated in a sealed plexiglass chamber filled with $95 \% \mathrm{O}_{2}, 5 \% \mathrm{CO}_{2}$. Air-exposed dishes were incubated in $95 \%$ air, $5 \% \mathrm{CO}_{2}$. The medium and chamber gas were changed daily. After $48 \mathrm{~h}$, the cells were harvested by gently rinsing the medium, then removing the adherent cells into buffer and sonicating on ice for antioxidant assays.

Each data point represents the antioxidant assay for an individual aliquot of the pooled cell preparation. Each antioxidant assay was performed on at least three separate cell preparations.

Biochemical assays. DNA was determined by the fluorometric assay of Cesarone et al. (14). Protein was assayed using the method of Lowry et al. (15) or with fluorescamine dye according to Bohlen et al. (16). SOD was assayed by monitoring the disappearance of superoxide anion as described by Marklund (17). Catalase activity was assayed by the method of Claiborne
(18). GP activity was measured according to Paglia and Valentine (19) using cumene hydroperoxide as a substrate. Glutathione (oxidized and reduced) was determined by the enzymatic assay of Griffith (20) using reduced glutathione as a standard. GR activity was assayed by the method of Carlberg et al. (21) and G6PD activity was measured according to Lohr and Waller (22). Hoechst dye was obtained from Aldrich Chemical Company, Milwaukee, WI. Other reagents were obtained from Sigma Chemical Company, St. Louis, MO.

Statistical analysis. Results are expressed as mean \pm 1 SD. Analysis of variance was used for in vitro studies. Student's unpaired $t$ test with correction for multiple comparisons was used for in vivo studies. Differences supported by $p<0.05$ were accepted as significant.

\section{RESULTS}

In vitro studies. Results for antioxidant assays of alveolar type II cells before (baseline) and after $2 \mathrm{~d}$ in vitro incubation in air or oxygen are shown in Table 1 . There were significant differences between baseline and in vitro incubation in air or oxygen for all the antioxidants (except GR in oxygen-exposed cells) when expressed per $\mu \mathrm{g}$ DNA. All the antioxidants except catalase increased in vitro. When expressed per $\mathrm{mg}$ protein, however, only G6PD and glutathione increased during in vitro incubation. The other antioxidants decreased during in vitro incubation when expressed per mg protein. The only significant differences between oxygen and air exposure were that GR/ $/ \mu \mathrm{g}$ DNA and $\mathrm{G} 6 \mathrm{PD} / \mu \mathrm{g}$ DNA were higher in air-exposed cells than in oxygenexposed cells.

In vivo studies. Results for antioxidant assays in whole lung homogenate and alveolar type II cells exposed to air or oxygen for $4 \mathrm{~d}$ in vivo are shown in Figure 1. When assayed in whole lung homogenate (left portion of each panel), all the antioxidants except SOD were significantly higher in animals that had been exposed to hyperoxia before death (hatched bars compared to open bars). These results are consistent with those obtained in previous studies by other investigators $(2,3)$. In control animals (open bars), catalase, GP, and GR were significantly higher in type II cells than in lung homogenate. G6PD and glutathione were significantly lower in type II cells than in lung homogenate. Assays in alveolar type II cells have also been expressed per $\mu \mathrm{g}$ DNA in Table 2. Only G6PD and glutathione were increased by oxygen exposure. SOD, catalase, and GR were decreased in type II cells during oxygen exposure. When type II cell antioxidants were expressed per mg protein (right portion of each panel in Fig. 1), G6PD and glutathione were again higher after exposure to oxygen (hatched bars) as compared to air (open bars). Catalase

Table 1. Antioxidants in alveolar type II cells before (baseline) and after 2 d exposure to $95 \%$ air or $95 \%$ oxygen in vitro*

\begin{tabular}{|c|c|c|c|c|c|c|}
\hline & \multicolumn{3}{|c|}{$\mathrm{U} / \mu \mathrm{g}$ DNA } & \multicolumn{3}{|c|}{$\mathrm{U} / \mathrm{mg}$ protein } \\
\hline & Baseline & Air & Oxygen & Baseline & Air & Oxygen \\
\hline $\begin{array}{l}\text { SOD } \\
(n)\end{array}$ & $\begin{array}{c}0.13 \pm 0.06 \\
(13)\end{array}$ & $\begin{array}{c}0.32 \pm 0.19 \dagger \\
(14)\end{array}$ & $\begin{array}{c}0.25 \pm 0.10 \dagger \\
(14)\end{array}$ & $\begin{array}{c}5.4 \pm 0.9 \\
(13)\end{array}$ & $\begin{array}{c}4.3 \pm 1.2 \dagger \\
(14)\end{array}$ & $\begin{array}{c}3.9 \pm 0.8 \dagger \\
(14)\end{array}$ \\
\hline CAT & $1.8 \pm 0.4$ & $1.2 \pm 0.4 \dagger$ & $1.3 \pm 0.5 \dagger$ & $42 \pm 8$ & $10 \pm 2 \dagger$ & $14 \pm 3 \dagger$ \\
\hline$(n)$ & $(20)$ & $(20)$ & $(21)$ & (20) & (20) & (21) \\
\hline $\begin{array}{l}\text { GP } \\
(n)\end{array}$ & $\begin{array}{c}1.3 \pm 0.3 \\
(15)\end{array}$ & $\begin{array}{c}2.0 \pm 0.7 \dagger \\
(15)\end{array}$ & $\begin{array}{c}2.3 \pm 0.8 \dagger \\
(15)\end{array}$ & $\begin{array}{c}35 \pm 14 \\
(15)\end{array}$ & $\begin{array}{c}17 \pm 6 \dagger \\
(15)\end{array}$ & $\begin{array}{c}25 \pm 11 \dagger \\
(15)\end{array}$ \\
\hline GR & $1.0 \pm 0.4$ & $1.8 \pm 1.1 \dagger$ & $1.3 \pm 0.04$ & $27 \pm 9$ & $18 \pm 6 \dagger$ & $16 \pm 5 \dagger$ \\
\hline$(n)$ & (13) & (13) & (13) & (13) & (13) & (13) \\
\hline $\begin{array}{l}\text { G6PD } \\
(n)\end{array}$ & $\begin{array}{c}0.7 \pm 0.2 \\
(15)\end{array}$ & $\begin{array}{c}2.8 \pm 1.1 \dagger \\
(16)\end{array}$ & $\begin{array}{c}1.9 \pm 0.5 \dagger \\
(15)\end{array}$ & $\begin{array}{c}19 \pm 4 \\
(15)\end{array}$ & $\begin{array}{c}31 \pm 10 \dagger \\
(16)\end{array}$ & $\begin{array}{c}27 \pm 6 \dagger \\
(15)\end{array}$ \\
\hline GLU & $0.3 \pm 0.1$ & $1.3 \pm 0.2 \dagger$ & $1.1 \pm 0.4 \dagger$ & $12 \pm 3$ & $25 \pm 13 \dagger$ & $25 \pm 18 \dagger$ \\
\hline$(n)$ & (12) & (15) & (15) & $(12)$ & $(15)$ & $(15)$ \\
\hline
\end{tabular}

* SOD - $\left(1 \mathrm{U}=\ln 2 / \mathrm{t}_{1 / 2} \mathrm{~s}^{-1}\right) ; \mathrm{CAT}$, catalase - $\left(\mathrm{U}=\mu \mathrm{mol} \mathrm{H} \mathrm{H}_{2} \mathrm{O}_{2} / \mathrm{min}\right) ; \mathrm{GP}, \mathrm{GR}, \mathrm{G} 6 \mathrm{PD}-(\mathrm{U}=$ nmol NADPH/min $)$; GLU $=$ glutathione, reduced + oxidized $-(\mathrm{U}=\mathrm{nmol}$ reduced $\mathrm{GLU})$.

$\dagger p<0.05$ when compared to baseline. (The only significant differences between oxygen and air exposure were that GR/ $\mu \mathrm{g} \mathrm{DNA}$ and G6PD/ $\mu \mathrm{g}$ DNA were higher in the air-exposed cells than in the oxygen-exposed cells.) 

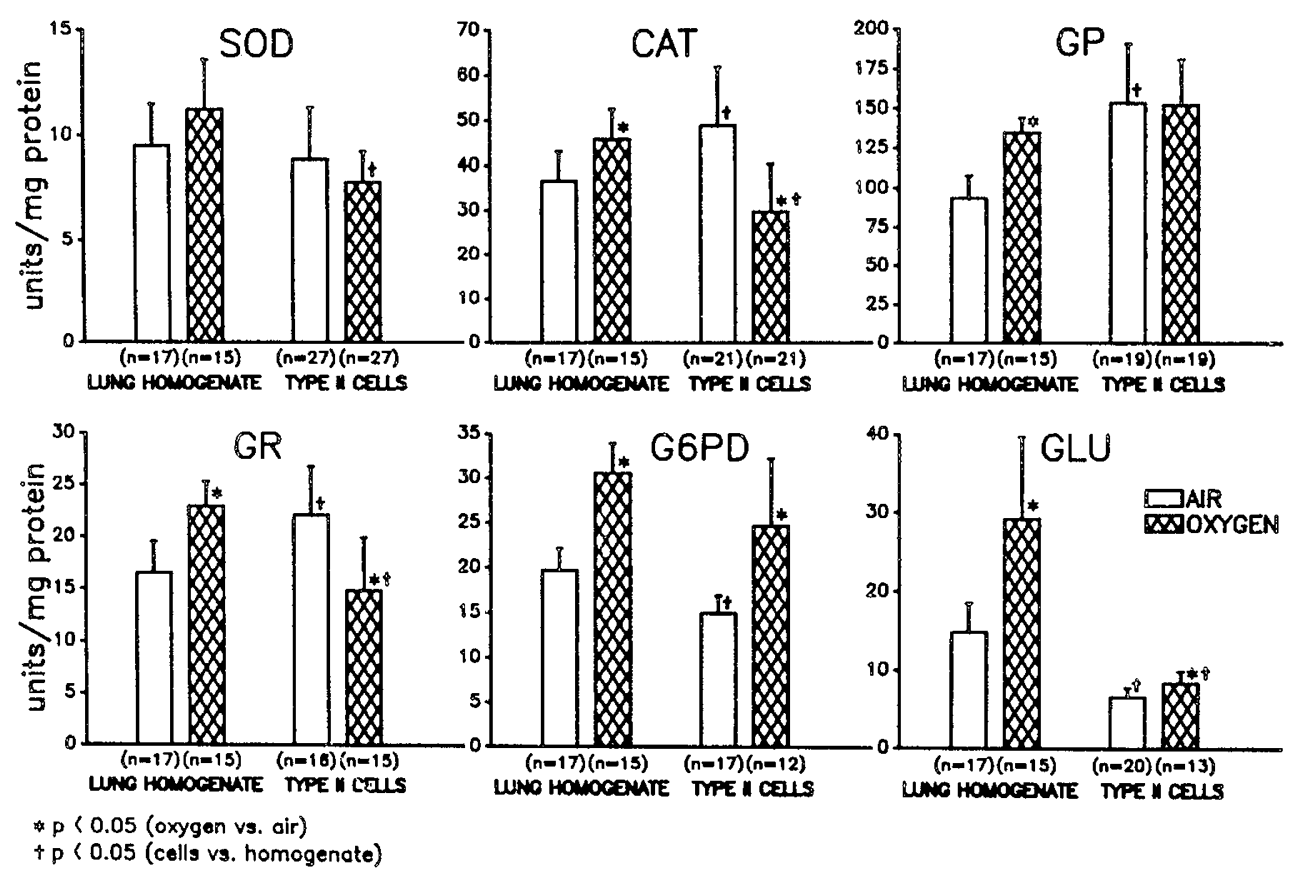

Fig. 1. SOD activity $\left(1 \mathrm{U}=\ln 2 / \mathrm{t}_{1 / 2} \mathrm{~s}^{-1}\right)$, catalase activity $(C A T)\left(\mathrm{U}=\mu \mathrm{mol} \mathrm{H}_{2} \mathrm{O}_{2} / \mathrm{min}\right)$, GP activity $(\mathrm{U}=$ nmol NADPH/min), GR activity $(\mathrm{U}$ $=\mathrm{nmol} \mathrm{NADPH} / \mathrm{min}), \mathrm{G} 6 \mathrm{PD}$ activity $(\mathrm{U}=\mathrm{nmol} \mathrm{NADPH} / \mathrm{min})$, and glutathione $(G L U)$ content, reduced + oxidized $(\mathrm{U}=\mathrm{nmol}$ reduced GLU), in lung homogenate supernatant and alveolar type II cells from newborn rats exposed to room air or $100 \%$ oxygen for $4 \mathrm{~d}$ in vivo.

Table 2. Antioxidants in alveolar type II cells after 4 d exposure to $95 \%$ air or $95 \%$ oxygen in vivo $(U / \mu g D N A)^{*}$

\begin{tabular}{cccccccc}
\hline & SOD & CAT & GP & GR & G6PD & GLU \\
\hline Air & $0.23 \pm 0.08$ & $1.5 \pm 0.3$ & $3.6 \pm 1.0$ & $0.53 \pm 0.07$ & $0.5 \pm 0.2$ & $0.15 \pm 0.03$ \\
Oxygen & $(27)$ & $(21)$ & $(19)$ & $(16)$ & $(17)$ & $(20)$ \\
& $0.19 \pm 0.06$ & $1.0 \pm 0.2 \dagger$ & $4.7 \pm 2.4$ & $0.41 \pm 0.18 \dagger$ & $1.0 \pm 0.2 \dagger$ & $0.22 \pm 0.05 \dagger$ & $(12)$ \\
\hline
\end{tabular}

* SOD - $\left(1 \mathrm{U}=\ln 2 / \mathrm{t}_{1 / 2} \mathrm{~s}^{-1}\right) ; \mathrm{CAT}$, catalase - $\left(\mathrm{U}=\mu \mathrm{mol} \mathrm{H} \mathrm{O}_{2} / \mathrm{min}\right)$; GP, GR, G6PD - $(\mathrm{U}=$ nmol NADPH$/ \mathrm{min})$; GLU = glutathione, reduced + oxidized $-(\mathrm{U}=$ nmol reduced GLU).

$\dagger p<0.05$ when compared to air.

and GR were lower after hyperoxia than in type II cells from control animals.

\section{DISCUSSION}

We examined the effects of hyperoxia on antioxidant enzymes and glutathione in vitro and in vivo. In the in vitro system, we were unable to show that hyperoxia causes an increase in any of the antioxidants we investigated. Even under control in vitro conditions ( $95 \%$ air, $5 \% \mathrm{CO}_{2}$ ), alveolar type II cells demonstrate increased antioxidants per $\mu \mathrm{g}$ DNA. Some of these antioxidants (SOD, GP, and GR) that were increased from baseline when expressed per $\mu \mathrm{g}$ DNA were not increased when expressed per $\mathrm{mg}$ protein. This finding would be consistent with an increase in cell volume and no change in antioxidant concentration under in vitro conditions. G6PD and glutathione were increased during in vitro exposure regardless of the denominator used. The increases that occurred in vitro were the same in both in vitro environments (95\% air and 95\% oxygen). Thus, G6PD and glutathione are increased by in vitro conditions but not by hyperoxia.

Although in vitro studies on alveolar type II cells allow for investigation of a single perturbation in an individual cell type, the cell's response to the perturbation may be very different from that which occurs in vivo. If type II cells in vivo require interaction with adjacent lung cells for induction of antioxidants as they do for other cell functions (23), we would have been unable to detect this response in the in vitro conditions of this study. We under- took the in vivo portion of this study to investigate this possibility. For comparisons between lung homogenate and type II cells in the in vivo portion of the study, antioxidants have been expressed only per $\mathrm{mg}$ protein because DNA/protein ratios of various lung cell types are likely to differ and differences expressed per $\mu \mathrm{g}$ DNA may simply reflect different cell volumes among different cell types. We determined that catalase, GP, and GR activities are $35-65 \%$ higher in type II cells than in lung homogenate. These results are different from those obtained for adult rats by Forman and Fisher (11) in which SOD, GP, and G6PD were higher in type II cells and Freeman et al. (12) who found only G6PD to be higher in type II cells than in lung homogenate. This difference may be explained by different cell composition of neonatal lung as compared to adult lung or by differences in the methods of sample preparation. Forman and Fisher (11) used overnight differential adhesion to isolate type II cells, and based on our in vitro studies this might be expected to increase type II cell antioxidants as an artifact of the isolation process. In contrast to these studies, we found that type II cells had less G6PD and glutathione than lung homogenate. Thus, if the neonatal type II cell's resistance to oxygen induced injury can be explained by higher constitutive levels of antioxidants, the protection would have to be mediated by higher catalase, GP, and GR. Increased activity of GP could result in depletion of reduced glutathione stores if there were insufficient G6PD to regenerate NADPH and oxidized glutathione was eliminated from the cell (24).

For the antioxidants that are higher in type II cells (catalase, 
GP, and GR) than in lung homogenate from control animals, concentrations are not higher than in lung homogenate from oxygen-exposed animals. Thus, the hyperoxia-induced increase in these antioxidants in lung homogenate is not attributable to hypertrophy or selective survival type II cells after exposure to hyperoxia.

Even if the neonatal alveolar type II cell does not have higher levels of antioxidants than other lung cell types, this cell might have antioxidant-mediated enhanced protection from oxidant injury if antioxidant levels could be increased during oxygen exposure. In contrast to studies of oxygen tolerant adult animals (exposed to $85 \%$ oxygen for 7 d) (12), we did not demonstrate increases in all the antioxidants when expressed per $\mu \mathrm{g}$ DNA as would be expected in alveolar type II cell hypertrophy with maintenance of cytosolic antioxidant concentrations. In the present studies, only G6PD and glutathione were increased when expressed either per $\mu \mathrm{g}$ DNA or per mg protein.

Previous studies in this laboratory have shown that the hyperoxia-induced increase in activity of G6PD is associated with comparable increases in the amount of enzyme protein (25). Increased G6PD might simply reflect increased metabolic activity in hyperoxia-exposed type II cells; this seems unlikely because oxidative metabolism is decreased during hyperoxia in lung tissue culture (26). Inasmuch as little is known about the coordination of concerted antioxidant enzyme systems, it is difficult to speculate whether an increase in G6PD activity alone could afford the cell protection from oxygen-induced injury.

Reduced glutathione serves as a reducing agent for peroxidation products of oxygen radicals. We did not assay oxidized glutathione or rates of glutathione synthesis. If glutathione synthesis was increased but glutathione was rapidly oxidized and released from the cells, biologically important protection could be afforded without increased glutathione measured at a single time point. The role of other nonenzymatic antioxidants, such as vitamins $A$ and $E$, in the type II cell's resistance to oxygen toxicity is unknown.

The findings in this study are consistent with the following conclusions. Neonatal alveolar type II cells do not have markedly higher constitutive levels of antioxidants than other cell types. The increase in lung antioxidants that occurs in neonatal rats during exposure to hyperoxia cannot be explained by a morphologic change toward alveolar type II cell predominance. If type II cell preservation during hyperoxia is explained by increased antioxidants during oxygen exposure, it is the glutathione system that mediates this protection.

Freeman et al. (12) suggested that enhanced SOD activity may be localized in endothelial cells which undergo hypertrophy during adaptation to sublethal hyperoxia in adult rats. Other cell types that are more prevalent in the lung after chronic hyperoxia are fibroblasts, macrophages, and neutrophils. If these cells are relatively rich in antioxidants, their enhanced presence in the lung could account for increased antioxidants observed in oxygen-tolerant states.
REFERENCES

1. Deneke SM, Fanburg BL 1980 Normobaric oxygen toxicity of the lung. N Engl J Med 303:76-85

2. Frank L, Bucher JR, Roberts RJ 1978 Oxygen toxicity in neonatal and adult animals of various species. J Appl Physiol 45:699-704

3. Yam J, Frank L, Roberts RJ 1978 Oxygen toxicity: comparison of lung biochemical responses in neonatal and adult rats. Pediatr Res 12:115-119

4. Tierney DF, Ayers L, Kasuyama RS 1977 Altered sensitivity to oxygen toxicity. Am Rev Respir Dis 115:59-65

5. Frank L, Roberts RJ 1979 Endotoxin protection against oxygen-induced acute and chronic lung injury. J Appl Physiol 47:577-581

6. Hazinski TA, Kennedy KA, France ML, Hansen TN 1988 Pulmonary $\mathrm{O}_{2}$ toxicity in young lambs: physiologic and biochemical effects of endotoxin infusion. J Appl Physiol 65:1579-1585

7. Kapanci Y, Weibel ER, Kaplan HP, Robinson FR 1969 Pathogenesis and reversibility of the pulmonary lesions of oxygen toxicity in monkeys II. Ultrastructural and morphometric studies. Lab Invest 20:101-118

8. Crapo JD, Barry BE, Foscue HA, Shelburne J 1980 Structural and biochemical changes in rat lungs occurring during exposures to lethal and adaptive doses of oxygen. Am Rev Respir Dis 122:123-143

9. Warshaw JB, Wilson CW, Saito K, Prough R 1985 The responses of glutathione and antioxidant enzymes to hyperoxia in developing lung. Pediatr Res 19:819-823

10. Richards RJ, Davies N, Atkins J, Oreffo VIC 1987 Isolation, biochemical characterization, and culture of lung type II cells of the rat. Lung 165:143158

11. Forman HJ, Fisher AB 1981 Antioxidant enzymes of rat granular pneumocytes: constitutive levels and effect of hyperoxia. Lab Invest 45:1-6

12. Freeman BA, Mason RJ, Williams MC, Crapo JD 1986 Antioxidant enzyme activity in alveolar type II cells after exposure of rats to hyperoxia. Exp Lung Res 10:203-222

13. Kikkawa Y, Yoneda K 1974 The type II epithelial cell of the lung 1. Method of isolation. Lab Invest 30:76-84

14. Cesarone CF, Bolognesi C, Santi L 1979 Improved microfluorometric DNA determination in biological material using 33258 Hoechst. Anal Biochem 100:188-197

15. Lowry OH, Rosebrough NJ, Farr AL, Randall RJ 1951 Protein measurement with the Folin phenol reagent. J Biol Chem 193:265-275

16. Bohlen P, Stein S, Udenfriend S 1973 Fluorometric assay of proteins in the nanogram range. Arch Biochem Biophys 155:213-220

17. Marklund SL 1985 CRC Handbook of Methods for Oxygen Radical Research. CRC Press, Boca Raton, FL, pp 249-255

18. Claiborne A 1985 CRC Handbook of Methods for Oxygen Radical Research. CRC Press, Boca Raton, FL, pp 283-284

19. Paglia DE, Valentine WN 1967 Studies on the quantitative and qualitative characterization of erythrocyte glutathione peroxidase. J Lab Clin Med 70:158-169

20. Griffith OW 1980 Determination of glutathione and glutathione disulfide using glutathione reductase and 2-vinylpyridine. Anal Biochem 106:207-212

21. Carlberg I. Altmejd B, Mannervik B 1981 Purification and immunological studies of glutathione reductase from rat liver. Biochim Biophys Acta 677:146-152

22. Lohr GW, Waller HD 1971 Methods of Enzymatic Analysis, Vol 2. Academic Press, New York, pp 636-643

23. Tanswell AK 1983 Cellular interactions in pulmonary oxygen toxicity in vitro: Hyperoxic induction of fibroblast factors which alter growth and lipid metabolism of pulmonary epithelial cells. Exp Lung Res 5:23-26

24. Willis RJ, Kratzing CC 1972 Changes in levels of tissue nucleotides and glutathione after hyperbaric oxygen treatment. Aust J Exp Biol Med Sci 6:725-729

25. Crouch LS, Prough RA, Kennedy KA, Snyder JB, Warshaw JB 1988 Rat lung antioxidant enzyme activities and their specific proteins during hyperoxia. $J$ Appl Physiol 65:797-804

26. Kimura RE, Thulin GE, Wender D, Warshaw JB 1983 Decreased oxidative metabolism in neonatal rat lung exposed to hyperoxia. J Appl Physiol 55:1501-1505 